\title{
Factors that Limit the Quality of Technical Maintenance in Rice Harvesting Machines in Cuba
}

ISSN: 2637-7659

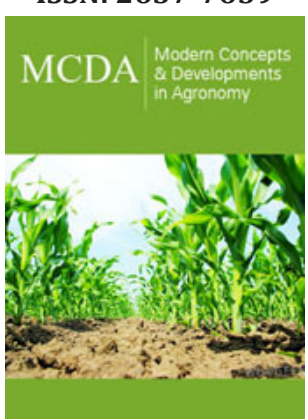

*Corresponding author: Alexander Miranda Caballero, Researcher and Professor (General Director), National Institute of Agricultural Sciences, Mayabeque, Cuba

Submission: 笽 September 03, 2021

Published: 海 September 07, 2021

Volume 9 - Issue 3

How to cite this article: Alexander Miranda Caballero, Calixto Domínguez Vento. Factors that Limit the Quality of Technical Maintenance in Rice Harvesting Machines in Cuba. Mod Concep Dev Agrono. 9(3). MCDA. 000712. 2021. DOI: 10.31031/MCDA.2021.09.000712

Copyright@ Alexander Miranda Caballero. This article is distributed under the terms of the Creative Commons Attribution 4.0 International License, which permits unrestricted use and redistribution provided that the original author and source are credited.

\section{Alexander Miranda Caballero ${ }^{1 *}$ and Calixto Domínguez Vento ${ }^{2}$}

${ }^{1}$ Researcher and Professor (General Director), National Institute of Agricultural Sciences, Mayabeque, Cuba

${ }^{2}$ Associate Researcher, Agricultural Engineering Research Institute, Pinar del Río, Cuba

\section{Opinion}

Within the technological process of rice production, the use of harvesting machines is a subject of undoubted interest. The deterioration and years of exploitation of the means used during the technical assistance of these equipment's, has caused a decrease in their technical availability, which affects productivity during the harvest. Hence the importance of the correct execution of technical maintenance and repair operations; to guarantee the operation of the machinery in operation, until they can be completely renewed, according to the economic possibilities of the country [1].

Cuba needs to import more than 400,000 tons of rice per year, so a strong investment program is carried out with the purpose of substituting imports and guaranteeing before 2030 a national production of at least $85 \%$ of the 700,000 tons of rice. that the country consumes annually. However, the average yields obtained in the last 25 years do not exceed 3.75t/ha and the traditional production system predominates in most areas where rice is grown, which requires a high degree of rice. mechanization (specialized cultivation), conditioned by the different sowing technologies that are used and the extensions that are destined for their exploitation [2]

In recent years, an improvement has been observed in the Cuban economy, which has a direct impact on the situation of the mechanized media that work in agriculture. The country acquires new agricultural techniques in small quantities, and takes steps for the gradual replacement of the aging machinery park, despite these positive signs for the future recovery of agricultural technology, it is evident that in the coming years the bulk of the work in the sector will continue to be made by the machinery available today, mostly affected by the lack of spare parts, the existence and operation of which largely depend on the quality of technical maintenance and repair work [3].

Within the technological process of rice production, the use of harvesting machines is a subject of undoubted interest. The deterioration and years of exploitation of the means used during the technical assistance of these equipments, has caused a decrease in their technical availability, which affects productivity during the harvest. Hence the importance of the correct execution of technical maintenance and repair operations; to guarantee the operation of the machinery in operation, until they can be completely renewed, according to the economic possibilities of the country. 
The deterioration of the machines demands a greater demand for technical assistance, and with it the need to organize the maintenance and repair process, drawing up strategies that ensure an optimal decision at all times based on maintainability criteria.

The results of the investigations carried out [4,5] showed that there are problems in ensuring the working capacity of the agricultural technique during the rice harvest and that they have an impact on the reliability, and that it manifests in:

a. Excessive shutdowns due to harvester failures during the harvesting process, which causes minimum values in productivity between $1.69 \ldots 2.34 \mathrm{t} / \mathrm{h}$;

b. Long waiting time of the machines, to eliminate the failures that occur during the harvest between $8.1 \ldots 10 \%$ of the day;

c. Insufficient organization of maintenance and repairs that cause loss of time for the management and search for spare parts that represent between $60 \ldots 80 \%$ of the fault elimination time.

Maintenance is responsible for preserving all the goods that make up the links of the system directly and indirectly, in the best operating conditions, with a good level of reliability, quality and at the lowest possible cost [6].

The daily maintenance is responsible for preparing the machine for daily work from the inspection, cleaning and lubrication of points according to the manufacturer's regulations, in addition, during its execution, anomalies in the mechanisms and systems are detected which can be corrected before starting. work, and therefore ensure the ability to work during the day.

Good technical maintenance depends on the proper functioning of the system or equipment, to perform these with the required quality, failures tend to decrease, since during their performance some of the possible failures are detected, a determining factor in reliability and consequently in the ease and economy of the execution of technical maintenance with quality. This characterizes the satisfactory fulfillment for a given time of the planned tasks; Therefore, it is ensured that the equipment performs its function satisfactorily for a given time, hence, there is a close relationship between technical maintenance and reliability, maintainability and availability.

Taking into account the influence of technical maintenance on the assurance of the combine's working capacity and the lack of knowledge of the level of compliance with technical maintenance and repairs in the scheduled time, they directly influence the ease and economy in the execution of maintenance and repairs taking into account the characteristics, design, assembly, operations, skills of the operators, environment, legislation or indications, spare parts, equipment.

To raise the level of maintainability of the combines and eliminate or reduce unproductive times, it is necessary to take into accountmeasures that facilitate ease and economy in the execution of maintenance and / or repair, taking into account the characteristics and previous events that occur. before the state of normality, design, assembly, operations, operator skills, modifications made, previous repairs, operation capacity, evaluation of management and maintenance operation, therefore it is necessary:

a. Look for administrative mechanisms that make it possible to reduce the loss of time waiting for documentation.

b. Create sufficiently reliable mechanisms that reduce the delay times for the extraction of parts from the warehouse.

c. Establish the ways so that the parts are distributed when they arrive at the central warehouse so that the personnel in charge can dispatch the parts at the required time and thus reduce the search time for personnel who authorize the extraction.

d. Comply with the demands of maintenance since through them it is possible to diagnose possible imperfections or failures during the work of the machines, which would undoubtedly avoid wasting time for the search and management of parts.

e. Create strategies that allow continuous training of maintenance personnel and operators, which would avoid waiting for qualified personnel to eliminate faults.

f. Replacing machine tools that have been in operation for more than 20 years and that are not in a position to face precision work, with modern ones that allow them to face the new incoming technology.

g. Create a continuous and differentiated training program that allows maintenance personnel to update the new technologies acquired by the country.

h. Take into account when acquiring new equipment, contract the supplier for the list of recommended spare parts to use during the first or the first two years of use of the equipment, which is usually cheaper.

Cuban agriculture, in order to raise the quality of maintenance in rice harvesting machines, needs to initiate a process of transition towards a change in the technologies they use. In short, the correct application of maintenance actions will allow the accumulation of experiences and technical knowledge that will generate organizational learning and technological capabilities that will influence subsequent decisions on the adoption of new technological changes.

\section{References}

1. Herrera E, Miranda A, Morejón Y, Paneque P (2017) Maintainability of New Holland Rice Harvesters in "Los Palacios" Company, Cuba. Agricultural Technical Sciences Magazine 26(4): 67-75.

2. Domínguez C, Miranda A, Guilherme A, Díaz G, Rodríguez A (2021) Adoption of technological innovations for conservation agriculture in rice cultivation in Cuba. Cuban Journal of Public and Business Administration 5(2): e167.

3. Shkiliova L Fernández M (2011) Technical maintenance and repair systems and their application in the agriculture. Revista Ciencias Técnicas Agropecuarias 20(1). 
4. Miranda A, Shkiliova L, Iglesias C, Anillo J (2003) Determination of the amount of technical maintenance of New Holland L520 rice harvesting machines. Revista Ciencias Técnicas Agropecuarias 12(3): 59-62.

5. Castell S, Miranda A, Díaz G, Pérez N (2015) Analysis of mechanization services in the agroindustrial company of grains "Los Palacios". Revista Ciencias Técnicas Agropecuarias 24(4): 45-51.
6. Mesa DH, Ortiz Y, Pinzón M (2006) Reliability, availability and maintainability, modern disciplines applied to maintenance. Scientia et Technica 12(30).

For possible submissions Click below:

\section{Submit Article}

